\title{
Bone Liposarcoma
}

National Cancer Institute

\section{Source}

National Cancer Institute. Bone Liposarcoma. NCI Thesaurus. Code C7598.

A very rare malignant adipose tissue neoplasm that arises from the bone. 